\title{
Annual Patterns of Atmospheric Pollutions and Episodes over Cairo Egypt
}

\author{
Y. Aboel Fetouh, ${ }^{1}$ H. El Askary, ${ }^{2,3,4}$ M. El Raey, ${ }^{1}$ M. Allali, ${ }^{5}$ W. A. Sprigg, ${ }^{3}$ and M. Kafatos ${ }^{2}$ \\ ${ }^{1}$ Institute of Graduate Studies and Research (IGSR), Alexandria University, Alexandria, Egypt \\ ${ }^{2}$ Center for Excellence in Earth Observing, Schmid College of Science and Technology, Chapman University, Orange, CA, USA \\ ${ }^{3}$ School of Earth and Environmental Sciences, Schmid College of Science and Technology, Chapman University, Orange, \\ CA 92866, USA \\ ${ }^{4}$ Department of Environmental Sciences, Faculty of Science, Alexandria University, Moharem Bek, Alexandria 21522, Egypt \\ ${ }^{5}$ School of Computational Sciences, Schmid College of Science and Technology, Chapman University, Orange, CA 92866, USA \\ Correspondence should be addressed to H. El Askary; elaskary@chapman.edu
}

Received 28 March 2013; Revised 13 July 2013; Accepted 18 July 2013

Academic Editor: S. K. Satheesh

Copyright (c) 2013 Y. Aboel Fetouh et al. This is an open access article distributed under the Creative Commons Attribution License, which permits unrestricted use, distribution, and reproduction in any medium, provided the original work is properly cited.

\begin{abstract}
The Nile Delta major cities, particularly Cairo, experienced stagnant air pollution episodes, known as Black Cloud, every year over the past decade during autumn. Low-elevated thermal inversion layers play a crucial role in intensifying pollution impacts. Carbon monoxide, ozone, atmospheric temperature, water vapor, and methane measurements from the tropospheric emission spectrometer (TES) on board the Aura have been used to assess the dominant component below the inversion layer. In this study, time series analysis, autocorrelations, and cross correlations are performed to gain a better understanding of the connections between those parameters and their local effect. Satellite-based data were obtained for the years 2005-2010. The parameters mentioned were investigated throughout the whole year in order to study the possible episodes that take place in addition to their change from year to year. Ozone and carbon monoxide were the two major indicators to the most basic episodes that occur over Cairo and the Delta region.
\end{abstract}

\section{Introduction}

Identifying the origin (natural versus anthropogenic) and dynamics of aerosols over different regions at varying temporal and spatial scales will provide more knowledge on impacts of aerosols on the regional climate and the ultimate connections to the Earth's global climate system [1]. Over the last decade, aerosols have been studied quantitatively regionally and globally using satellite remote sensing and modeling. Such studies proved to be very useful in climate studies $[2,3]$. The Mediterranean basin aerosols originate from a variety of sources, which are either natural (sea salts, desert dust) or anthropogenic (local sources) due to the increasing urbanization and industrialization, as well as longrange transport [4-6]. At regional scale, the Mediterranean is exposed to air pollution with levels exceeding the typical air-quality standards. This is particularly true for the Delta region, being at the crossroads of different aerosol species originating from local urban-industrial and biomass-burning activities, regional dust sources, and European pollution from the north [7-9].

Over the past decade Cairo, Egypt, located at a longitude of $31^{\circ} 13$ and latitude of $30.2^{\circ}$, the largest city of Africa and one of the world's megacities with a population of more than 20 million people and more than one third of the national industry, has been suffering from major air pollution problems. Cairo and the Greater Delta region have recorded much higher air pollution episodes as compared to the past few decades. As a result, it is also one of the most air-polluted megacities in the world [10]. This is a normal consequence of Egypt's accelerated economic growth over the past three decades. A growing population has increased the polluting human activities that include fuel combustion, and polluting factories such as in the cement industry that tries to keep up with the needs of the growing population. In addition to the city's economic growth, Cairo's location, 
topography, and complex climate systems play vital roles in the presence of these episodes [11-13]. Its location subjects it to blown sand and dust from the western desert (since Egypt is $90 \%$ desert), air pollutants transported from Europe, emissions of atmospheric constituents from Africa, and the effect of trade winds that diminish over the Mediterranean during the Black Cloud episodes. It is thought that "black cloud" pollution episodes occur only over Cairo and are due to local emissions. However, it was found that emissions from the surrounding cities and regions are contributing to Cairo's pollution [14]. The low topography of Cairo, bounded by Giza (western highlands) and Mokatam (eastern highlands), confines the pollutants and suppresses the motion of suspended particulates, especially in September through November when wind currents are weak [15]. Hence, wind patterns and humidity influence the behavior of air pollutants and must be considered [12].

Aerosol sources, types, and trajectories over the Nile Delta are complex and so is its meteorology. The worst air quality conditions over Cairo and its environs occur in the fall season $[12,16]$. This high-pollution season is locally referred to as the "black cloud" phenomenon, during which the region suffers from high ambient concentrations of atmospheric pollutants including particulates (PM), carbon monoxide, nitrogen oxides, ozone, and sulfur dioxide [1720]. During winter, the climate is generally cold and rainy while hot and dry in the summer; hence, the city witnesses significant climatological impacts on the public health [21]. On the other hand, Alexandria, a Mediterranean city, has a more appealing climate but is the largest industrial city, with $\sim 55 \%$ of the total Egyptian industry. Alexandria suffers from pollution episodes, which are, however, still not as intense as those usually observed over Cairo. It was revealed that Cairo's and Alexandria's aerosols include "background pollution," "pollution-like," and "dust-like" components [19, 20]. Generally speaking, Egypt is influenced by the regionalscale trade wind system which is enhanced during the warm season and results in winds over Egypt from the North supported by sea breezes along the Mediterranean coastline $[5,6,20]$. During autumn, aerosols originating from biomass burning from agricultural fields within the Nile Delta add to the area's anthropogenic aerosols and to bigger pollution events.

The published literature attributes the increased pollution levels over Cairo and the Nile Delta region during the black cloud season to emissions from biomass or open burning of agricultural waste and from vehicles, industries, and formation of secondary aerosols [12, 13, 16-19, 22-28]. Major contributors to PM10 over Cairo include, mobile source emissions, and open burning, while the PM2.5 tended to be dominated by mobile source emission, open burning, and secondary species [18]. Such episodes of pollution over densely populated cities such as Cairo severely impact public health [21], with potential adverse consequences, not only for the residents but also for the millions of visitors that tour this region annually, particularly from Europe, North America, and Japan. Identifying correct sources of aerosols is important not only for public health reasons but also for assessing their effect on the regional climate.
It is noteworthy that transport processes on a seasonal scale in the African upper troposphere are driven by Hadley meridional circulation which is strong during winter. In the summer, the pollutant transport is from the east, a result of the Asian monsoon anticyclone in April and May. During Africa's Northern Hemisphere monsoon season, ozone precursors generated from biomass burning in the south are transported to the Intertropical Convergence Zone and they change the composition of Africa's upper troposphere [29]. Smoke or air pollution concentrations are the highest with low wind speeds, low vertical turbulence, temperature inversions, and high humidity [30]. Therefore, it can be seen that the North African/East Mediterranean troposphere is a crossroad to various transport processes both on regional and intercontinental scales. A study on this pollution crossroad showed that pollution generated by Asia can be transported towards Africa by the anticyclone flow of the Asian summer monsoon [29].

\section{Data and Methodology}

Monitoring by new tropospheric satellite sensors is playing an increasingly important role in explaining chemistry and transport processes in the lower atmosphere [31]. Data from the Tropospheric Emission Spectroradiometer (TES) aboard the NASA satellite Aura, have been used in scientific analysis since 2006. The TES was found to be unique in providing multiyear coincident tropospheric profiles of $\mathrm{CO}, \mathrm{O}_{3}$, and $\mathrm{H}_{2} \mathrm{O}$. TES retrievals of ozone, temperature, and water vapor were compared to model fields from Global Modeling and Assimilation Office (GMAO). Temperature retrievals from the Atmospheric Infrared Sounder (AIRS), tropospheric ozone columns from Goddard Earth Observing System (GEOS), and ozone retrievals from Total Ozone Monitoring System (TOMS) were also compared and the results showed no biases [32]. In 2007, TES nadir observations were compared with nearly coincident spectral radiance measurements from AIRS on Aqua, and special scanning high-resolution interferometer sounder (SHIS) positively validated these TES measurements [33]. TES data have also been used in studying the effect of the $2006 \mathrm{El}$ Nino over Indonesia [34, 35]. The Atmospheric Chemistry Experiment (ACE) measurements were used, and it was found that the vertical profiles agree with those from the TES [34]. TES transect observations were applied in addition to the TES standard products to study low tropospheric ammonia and methanol over and near Beijing in northeast China [36]. This was the first time that these molecules were detected in space-based nadir viewing measurements penetrating in the lower atmosphere. Ozone concentrations from TES were used to examine the migration of high ozone over the western North Atlantic [37].

The objective of this paper is to report the results of a study investigating satellite-based TES observations of indicators contributing to air pollution episodes in Cairo, Egypt. TES and the Aura satellite are part of the Earth Observing System (EOS), a coordinated series of polarorbiting and low-inclination satellites [37]. Aura, launched on July 15, 2004, was designed to record lower stratosphere and 
upper troposphere compositions to study the atmosphere's chemistry and dynamics [38]. Data from the Aura mission are useful when studying ozone trends, air quality, and links to climate change [39]. The TES, an infrared, high-resolution, Fourier Transform spectrometer with a spectral range of 650 $3050 \mathrm{~cm}^{-1}(3.3-15.4 \mu)$ and a spatial resolution of $0.1 \mathrm{~cm}^{-1}$ nadir viewing and $0.025 \mathrm{~cm}^{-1}$ limb, is designed to measure the global, vertical distribution of tropospheric ozone and its precursors, such as carbon monoxide, with high precision [34]. In cloud-free conditions, the vertical resolution of TES nadir ozone estimates is about $6 \mathrm{~km}$ with sensitivity to both the lower and upper tropospheres [40].

The TES parameters considered in this study are atmospheric temperature (TATM), ozone $\left(\mathrm{O}_{3}\right)$, carbon monoxide (CO), methane $\left(\mathrm{CH}_{4}\right)$, and water vapor $\left(\mathrm{H}_{2} \mathrm{O}\right)$. $\mathrm{CO}$ and ozone are two pollutants used by the US Environmental Protection Agency (EPA) to monitor air quality and are measured globally and simultaneously by the TES instrument [34]. TES data for CO, methane, ozone, atmospheric temperature, and water vapor were collected for study from 2005 to 2010 using the Giovanni website. These unique data sets of vertical estimates of ozone and the key signature of pollution, carbon monoxide are available from TES. Vertical profiles can help in unraveling the processes that have a role in the redistribution of ozone [41]. A time series is first done to see when the highest values of CO, ozone, and methane occur. Data for these specific days corresponding to the high values are then presented in vertical profiles. Units for the values below are in volume mixing ratio (VMR).

\section{TES Data Analysis}

3.1. Vertical Profiles. The vertical distribution of ozone is crucial in Earth's atmosphere since the ozone filters out biodamaging ultraviolet (UV) light (wavelength $<280 \mathrm{~nm}$ ) in the stratosphere, acts as a greenhouse gas in the upper troposphere, regulates the oxidation capacity of the lower atmosphere, and affects the air quality for humans and vegetation near the Earth's surface [42]. On the other hand, atmospheric carbon monoxide (CO) distributions are controlled by anthropogenic emissions, biomass burning, transport, and oxidation by reaction with the hydroxyl radical $(\mathrm{OH})$. Hence, vertical profile distributions of $\mathrm{CO}$ are important for understanding changes related to all of these contributions [43]. Figure 1 shows three graphs for the five parameters during the summer June-July season during 3 different years 2005, 2006, and 2007.

In Figure 1, the gradient of atmospheric temperature is small. Ozone increases with altitude, perhaps an indication of abnormal conditions or the presence of abrupt temperature changes. In short, there is an absence of the "normal" situation during the summer season. Vertical Profiles for chosen dates, during the Black Cloud episode (OctoberNovember), are shown in Figure 2.

During the black cloud episode, CO levels indicate the presence of pollution. Levels of $\mathrm{CO}$ were also high in the the dust season, March through April. The presence of methane, water vapor, and other greenhouse gases such as carbon dioxide in the Cairo atmosphere heat, the air creates an inversion aloft and conspire to trap pollutants below. Aerosols were found to peak during March and June due to mineral dust, part of the mix transported into Cairo [27] from the Sahara desert.

It is clear from this evidence that meteorological factors, coinciding with Cairo's pollution and heat-island conditions make the analysis a complicated process. However, the available literature leads us into profitable directions: increase in Ozone during the summer is mostly a result of transboundary transport from Europe [44]; carbon monoxide increases are a result of pollution and the effect of Sahara cyclones (Khamsin) or the Saharan depression that increases dust and aerosols during the same time period [16].

3.2. CO and Ozone Time Series. Figures 3 and 4 show the trend of ozone and carbon monoxide levels at four different pressure levels: $100 \mathrm{hPa}, 908 \mathrm{hPa}, 825 \mathrm{hPa}$, and $749 \mathrm{hPa}$ over the year 2007.

Many peaks can be observed throughout the year. Oscillations are clear during February, July-August, and OctoberNovember. Ozone is at its highest levels during the summer season. This is mainly attributed to long range transport from Europe [44]. Recent studies in 3D atmospheric chemistry and transport models suggest that the photochemical ozone formation from biomass burning may be less important than it was indicated in previous studies and that biomass burning may not be the main cause for an increase in tropospheric ozone $[45,46]$.

Studying the tropospheric ozone using aerosol index and tropospheric column ozone (TCO) time series, a TCO peak was noted over North Africa in the September through November time period and a minimum during early spring (February and March) [45, 46]. It was found that the photochemical smog occurs during the summer season and VOCs play an important role in the formation of ground level ozone, photochemical oxidants, and smog episodes [47]. In our case, October-November period in Egypt represents the black cloud season when the burning of rice straw increases Cairo's pollution; however, a high aerosol peak is found during March 2007 at the pressure level of $825 \mathrm{hPa}$.

Pollution peaks are clearly present in February, March, and April, 2007, reaching as high as 2.08E-7 vmr in March. Oscillations in concentration occurred throughout 2007 and were typical in 2006 as well (not shown here). High levels of carbon monoxide in March and April coincide with the presence of the dust season or Khamsin coming from the western desert. The high levels appearing during October and December of 2007 could be a cause of the Black Cloud episode.

Using trajectory analysis and satellite observations from MOPITT CO over the East/Japan Sea (level 2 data with 10\% precision for April 2000) for a case study in northeast Asia, it was shown that regional pollution and biomass burning play important roles in raising carbon monoxide concentrations [48].

Figure 5 shows the Aerosol Optical Depth (AOD) obtained from MODIS and the atmospheric temperature 


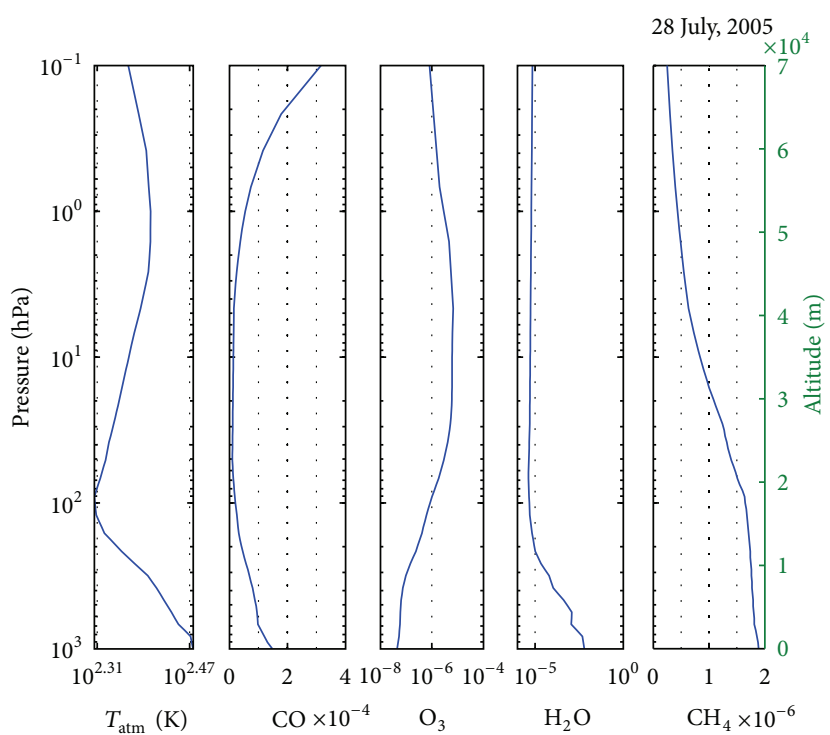

(a)

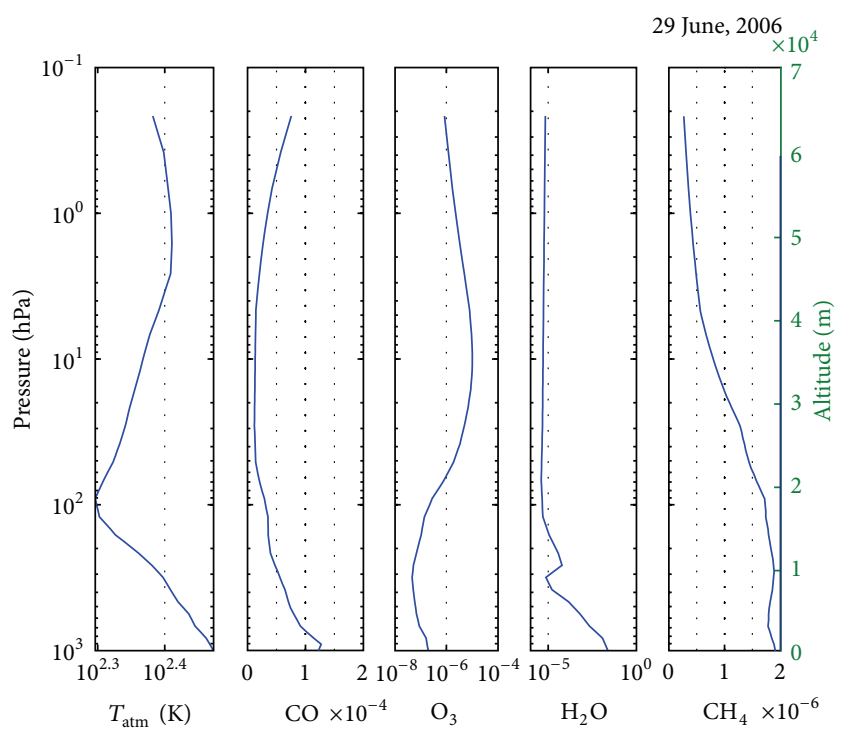

(b)
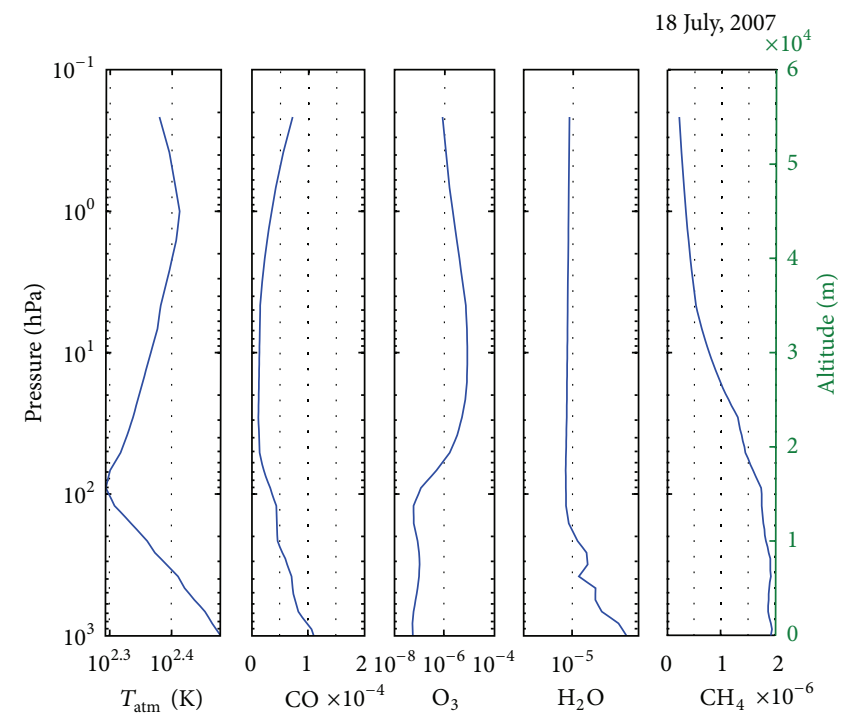

(c)

FIGURE 1: Vertical profiles of TES-derived parameters for selected summer months and days during 2005, 2006 , and 2007.

observations from TES at $908 \mathrm{hPa}$. High AOD values were found on 14/9/05, 25/3/06,31/7/06, 16/8/06, 13/4/07, and $6 / 10 / 07$ indicating about two highs per year with about 5 months between each maximum value. Maximum values correspond to the three major pollution periods of the year. Yet the bimodal distributions indicate two seasonal effects that correspond with the dust season in Feb-March and black episode in Sept-Oct. Low AOD values were observed on 19/12/05, 28/5/06, 23/1/07, 19/8/07, and 9/12/07 which occur either before or after an episode (dust storm, summer pollution, and black cloud). On the other hand, high temperature values were observed on $13 / 8 / 05,13 / 6 / 06,17 / 9 / 06,3 / 8 / 07$, and $22 / 10 / 07$ where low values were noted for $21 / 2 / 06,8 / 2 / 07$, and $25 / 12 / 07$. It is noteworthy that low temperature values occur during February where a relatively high AOD is observed.
3.3. Cross Correlations. Data used in this study was obtained from the TES Giovanni website between the years 2005 and 2010 for an area bordering latitude $(29.595,30.12)$ and longitude $(30.113,31.425)$. A 175-day lag was done for 705 observations recorded almost every two days and undergoing quadratic trend removal with a $95 \%$ confidence level.

Figure 6 shows cross correlations for water vapor and carbon monoxide against ozone, respectively. The cross correlation between ozone and water vapor has 22 out of 351 significant coefficients at a $95 \%$ confidence level. The crosscorrelation for ozone and water vapor revealed an anti correlation agreeing with the previous time series analysis of tropospheric ozone and water vapor that are negatively correlated throughout most of the tropics [49]. The rising of the tropospheric air masses associated with convection 


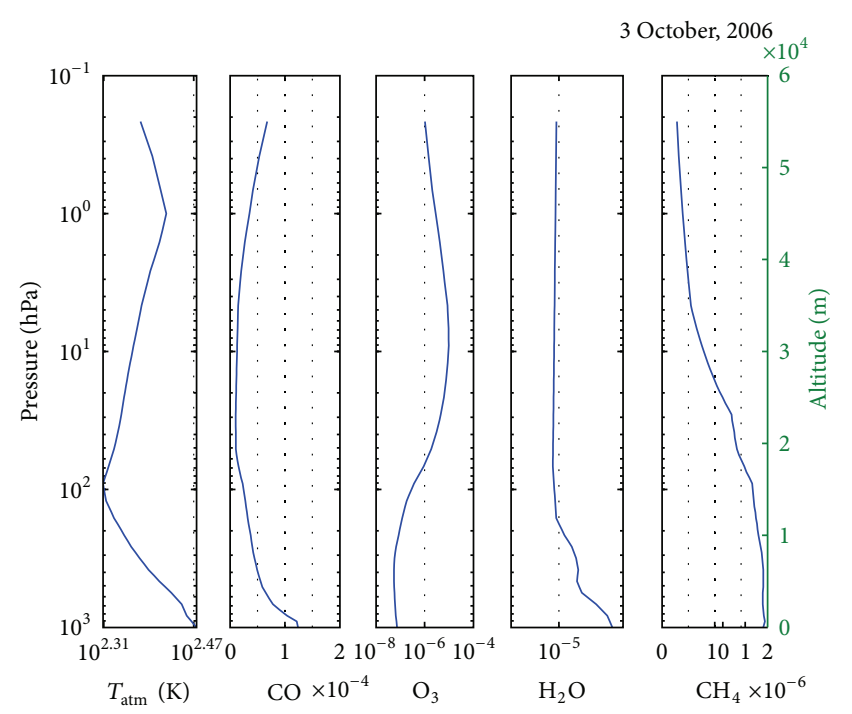

(a)

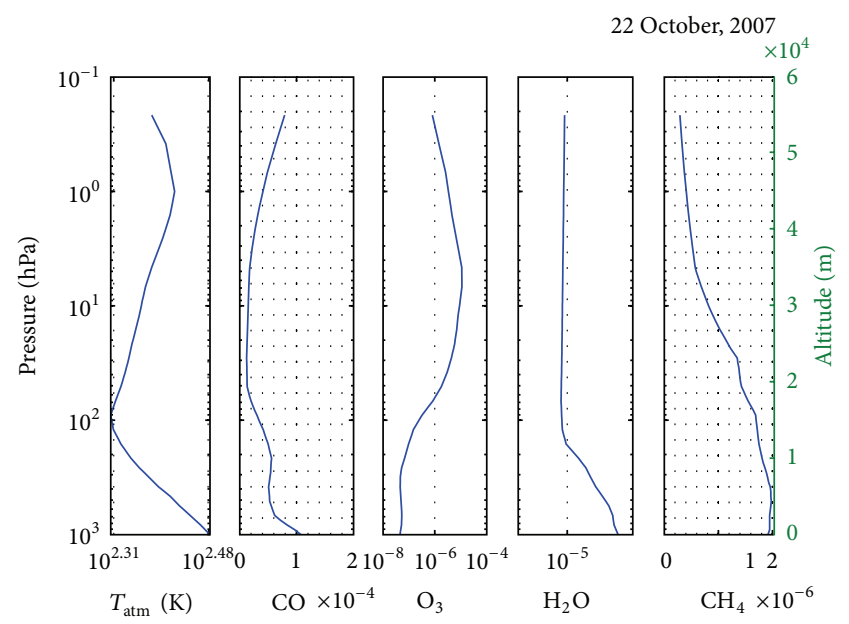

(c)

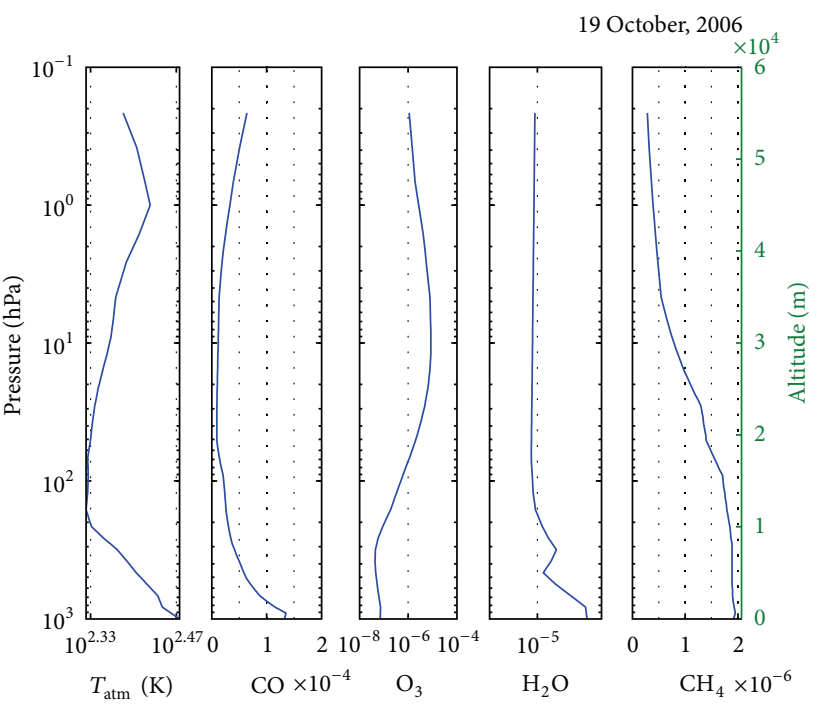

(b)

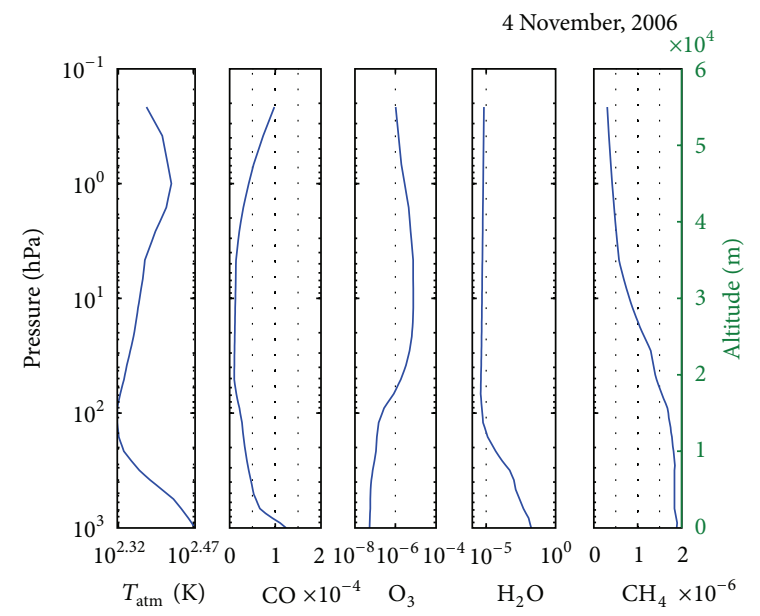

(d)

FIGURE 2: Vertical profiles of TES-derived parameters for selected dates experiencing the black cloud pollution episode during 2006 and 2007.

is a source for the large intertropical seasonal oscillation amplitudes and the anticorrelation measured between tropospheric ozone and water vapor in the tropics. This negative correlation can also be attributed to cloud-lightning $\mathrm{NO}_{x}$ (which generates ozone) together with transport effects, in addition to the movement of the tropopause as well as to the transport of low water vapor into a region that may increase the lifetime and abundance of ozone [49]. On the other hand, the cross-correlation between carbon monoxide and ozone shows somewhat symmetrical pattern of oscillations occurring approximately every 85 days. Previous studies have shown a significant correlation of carbon monoxide with ozone [48]. However, CO measurements were used to explore the correlation between biomass burning and ozone profiles and it was found that these correlations are rather complicated [50].

Figure 7 shows the cross correlations of night atmospheric temperatures with various measured parameters at a lag of 175 days for the years 2005-2010. Day atmospheric temperature measurements did not coincide with the rest of the parameters, so they were disregarded. Figure 7(a), shows a time delay between temperature and carbon monoxide (measured from minimum to maximum) of about 100 days and a strong anticorrelation exists at zero lag. There are statistically 35 significant coefficients out of 351 at a $95 \%$ confidence level. On the other hand, the relation between atmospheric temperature and ozone shows a more defined pattern than with carbon monoxide, indicating a higher degree of dependence (Figure 7(b)). This time the significant coefficients are 24 with a 95\% confidence level. The concentration of ozone increases to the maximum with an increase in temperature after 40 days. However, the cross correlation between atmospheric temperature and water vapor highlighted that small amounts of water vapor can result in great variations of air temperature [51]. Here, there are 33 significant coefficients at a 95\% confidence level. 


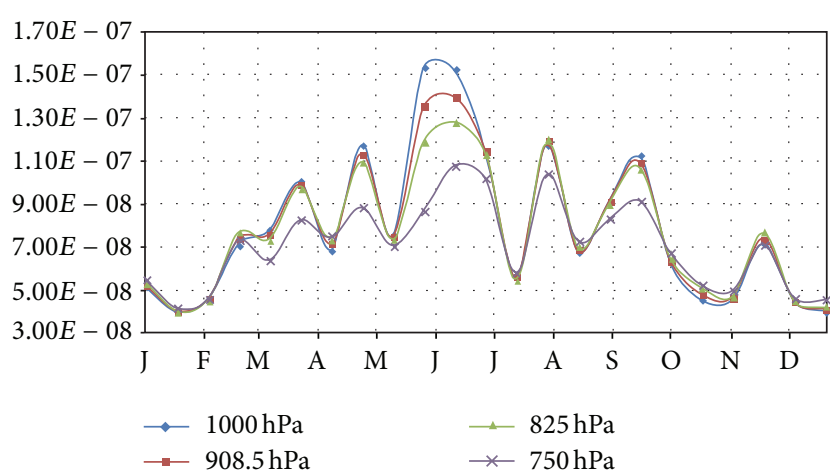

FIgURE 3: Time series for ozone measurements during 2007 concentrating on four different pressure levels, $749 \mathrm{hPa}, 825 \mathrm{hPa}, 908 \mathrm{hPa}$, and $1000 \mathrm{hPa}$, generated from TES, Aura.

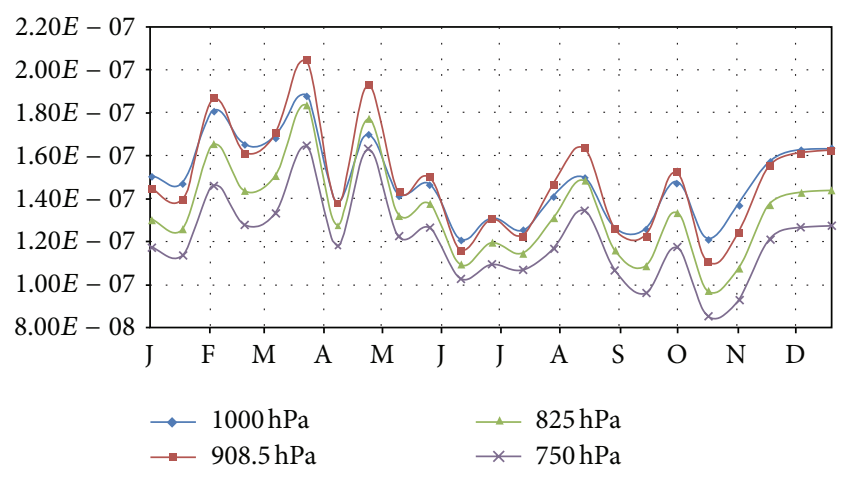

FIGURE 4: Time series for carbon monoxide measurements during 2007 concentrating on four pressure levels at $749 \mathrm{hPa}, 825 \mathrm{hPa}$, $908 \mathrm{hPa}$, and $1000 \mathrm{hPa}$.

Previous figures showed that water vapor displays a strong oscillation and a seasonal pattern which could be the effect of temperature changes. We found that monthly AOD means are anticorrelated with monthly precipitation, which suggests that precipitation is not only vital in winter aerosol removal processes but also in the accumulation of particles during summer $[2,16]$. This is confirmed through a study where the seasonality of surface temperature and of convection, as well as seasonal variations in monsoon circulation, produce associated seasonal changes in water vapor in the troposphere [51].

\section{HYSPLIT Back Trajectories and MODIS Fire Counts}

We have used the NOAA Air Resources Laboratory (ARL) HYSPLIT model (HYbrid Single-Particle Lagrangian Integrated Trajectory) Model access via NOAA ARL READY Website (http://www.arl.noaa.gov/HYSPLIT.php) NOAA Air Resources Laboratory, College Park, MD. for computing trajectories over Cairo. Gridded meteorological data, at regular time intervals, are used in calculation of air mass trajectories. Data for the back trajectories are obtained from existing archives.
Four HYSPLIT back trajectories were generated, each representing a season. Three altitudes were considered, $500 \mathrm{~m}, 700 \mathrm{~m}$, and $900 \mathrm{~m}$. Low altitudes below $1 \mathrm{~km}$ were used because it was found that anthropogenic pollutants during September, October, and November are found at low altitudes [52]. A corresponding wind rose at $950 \mathrm{mb}$ was added to show the dominant wind direction for 6 hours for further investigation.

The back trajectories of the major months having episodes occurring are studied using a one-day back trajectory (Figure 8). The air mass back trajectories are done at three different heights to locate the vertical extent of the different contributions in the pollution during air pollution episodes [52]. We assume that at these heights an inversion layer may appear to take place since anthropogenic pollutants occurring especially in mid-October and November hang at low altitudes. The presence of inversion layers traps the pollutants at a low elevation causing them to increase in concentration [52]. This causes the haze that can be seen hovering over Cairo during the black cloud episode.

During the second half of the year, the wind speed is less as can be seen from the wind rose in July and November. Thus, weaker convection would favor aerosol accumulation. This coincides with the increase of ozone during the summer and the increase of CO during autumn. Fire counts from MODIS in Figure 9 show the highest values are during the months of the black cloud episode, September, October, and November over a period of 7 years. A closer look showed the highest activity to have occurred during the years 2006 and 2007 [26]. The timing was found to coincide with the practicing of burning open field wastes, during September till November. Details on this can be found in Marey et al., 2010 [26].

\section{Results and Discussion}

In addition to Cairo's economic growth, its location, topography, and complex climate systems play vital roles in the presence of black cloud episodes. Its location subjects it to blown sand and dust storms from the western desert (since Egypt is 90\% desert), transformation of air pollutants from Europe, emissions of atmospheric constituents from Africa, and the effect of trade winds diminishing over the Mediterranean during black cloud periods. The topography of Cairo city, between the eastern and the western highlands, blocks the pollutants and suppresses the motion of the suspended particulates, especially from September through November when wind currents are weak. In winter, transport processes in the African upper troposphere are driven by the strong winter Hadley Meridional circulation. Wind and humidity are two factors that influence the behavior of air pollutants.

In summer, the effect of wind and humidity is from the east and the Asian monsoon anticyclone. During Africa's Northern Hemisphere April-May monsoon, ozone precursors generated from biomass burning in the south are transported to the Intertropical Convergence Zone and affect the composition of Africa's upper troposphere [29]. Smoke or air pollution concentrations are highest with low wind 


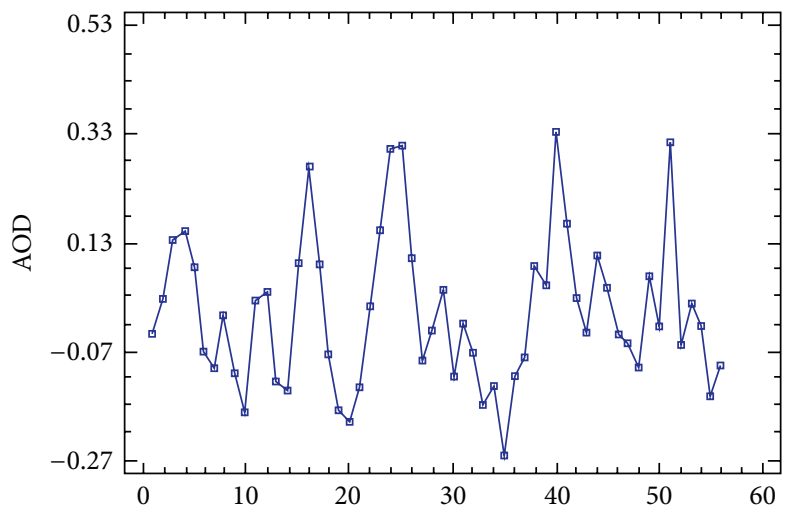

(a)

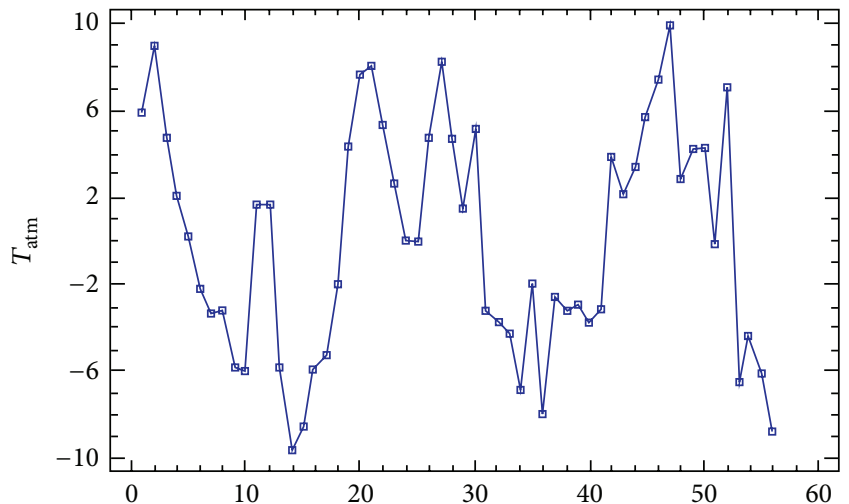

(b)

FIGURE 5: Time series for (a) aerosol optical depth measurements generated using MODIS data and (b) atmospheric temperature at $908 \mathrm{hPa}$ generated using TES data.

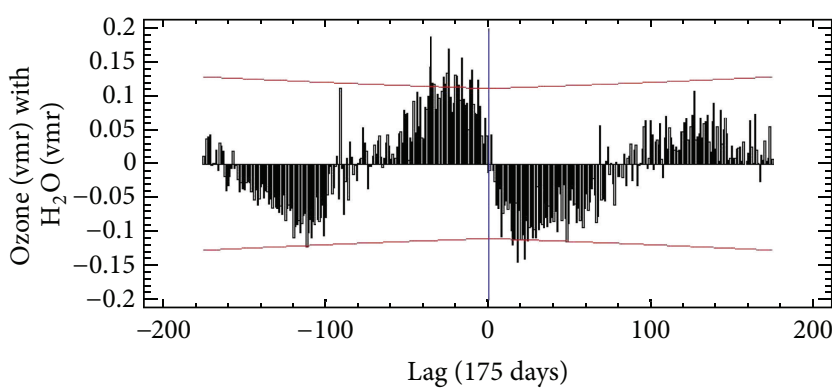

(a)

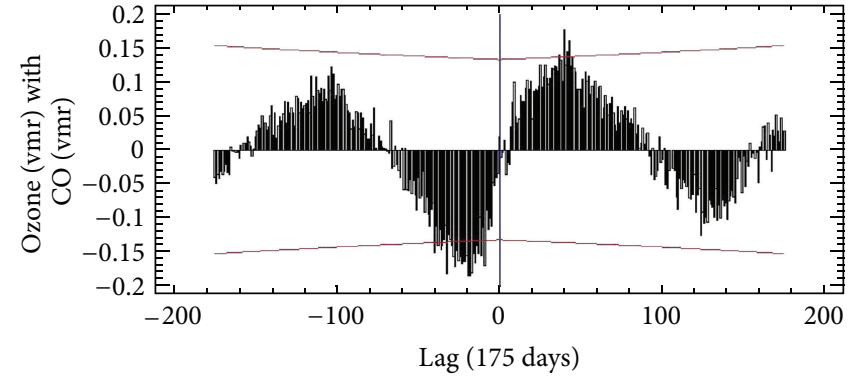

(b)

FIGURE 6: Cross correlation between ozone and (a) water vapor and (b) carbon monoxide for years 2005-2010.

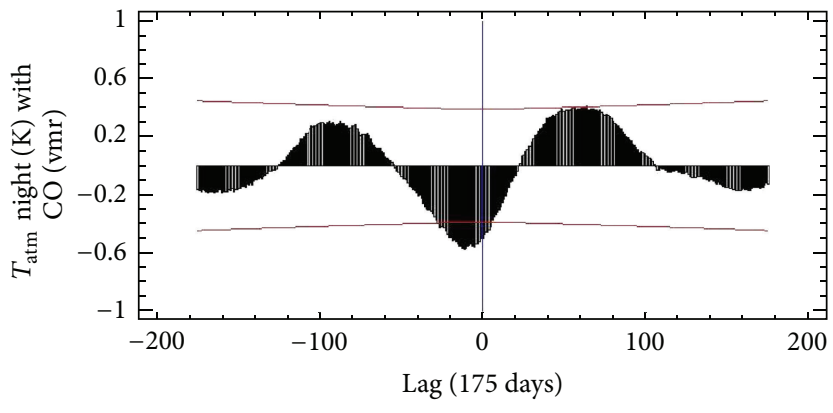

(a)

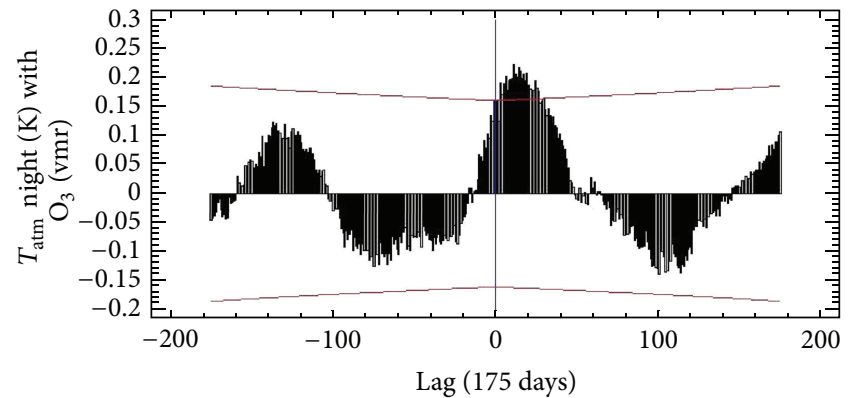

(b)

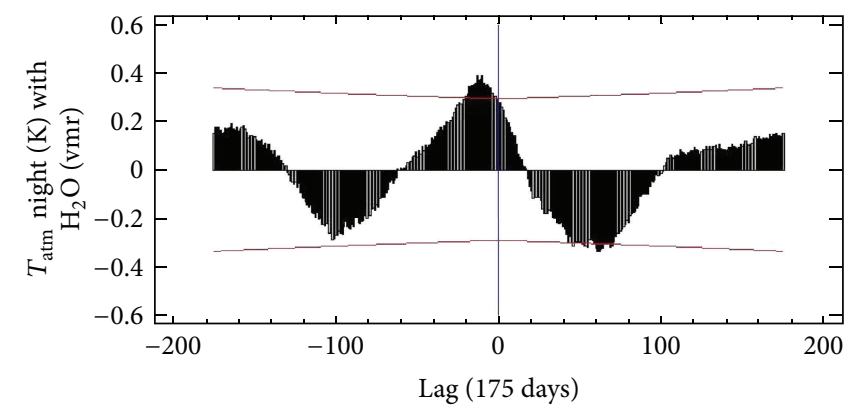

(c)

FIGURE 7: Cross correlation of night atmospheric temperature with CO, ozone, and water vapor, respectively. 


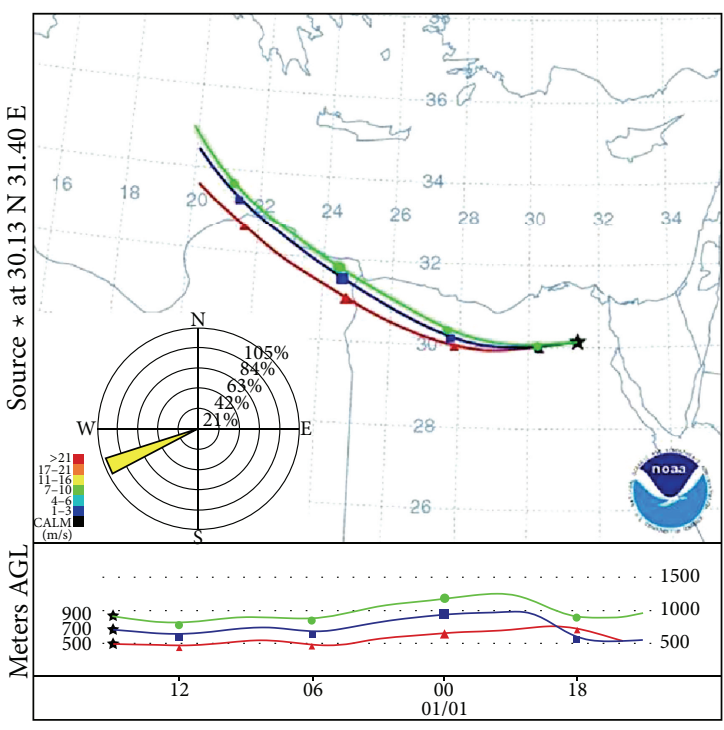

(a) 1st January, 2012 (winter)

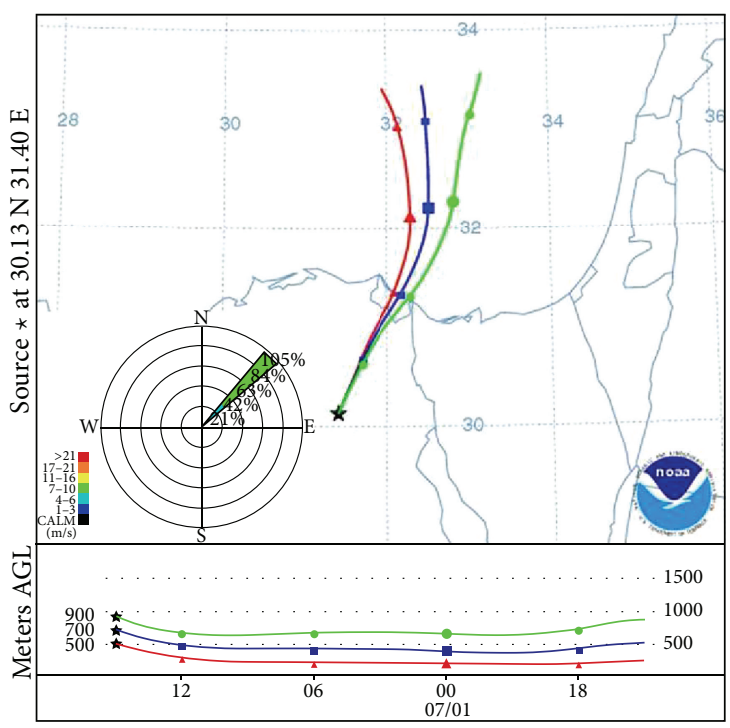

(c) 1st July, 2012 (summer)

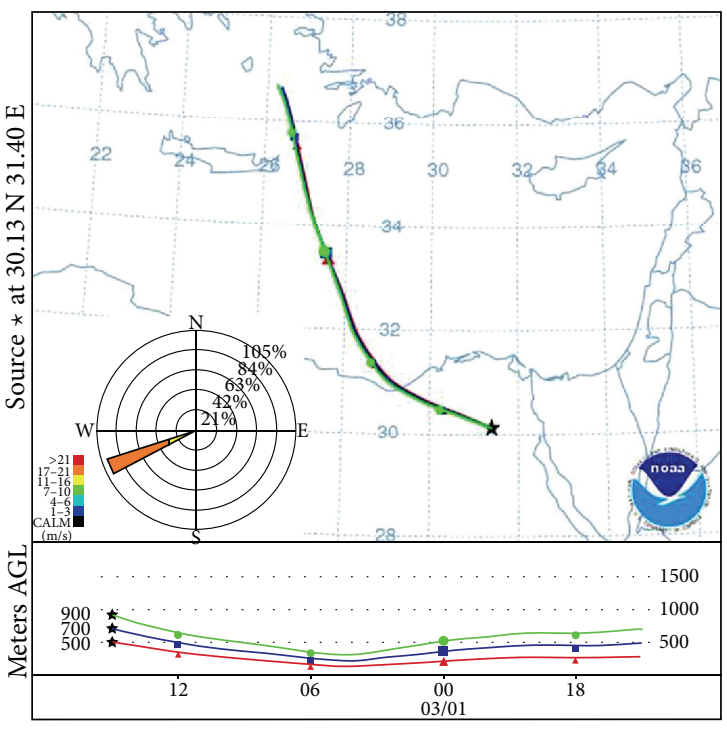

(b) 1st March, 2012 (spring)

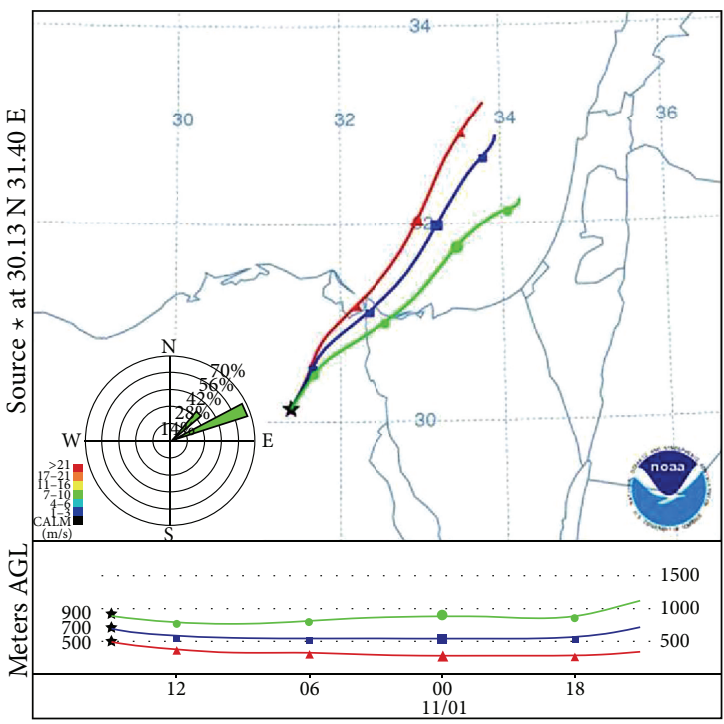

(d) 1st November, 2012 (autumn)

FIGURE 8: HYSPLIT and wind rose graphs for the four seasons in 2012. Three altitudes were considered: green $900 \mathrm{~m}$, blue $700 \mathrm{~m}$, and red $500 \mathrm{~m}$. Win drose was generated at $950 \mathrm{mb}$.

speeds, low vertical turbulence, temperature inversions, and high humidity [30]. Therefore, it can be seen that the North African/East Mediterranean troposphere is a crossroad to various transport processes on both regional and intercontinental scales. A study on this pollution crossroad showed that pollution generated by Asia can be transported towards Africa by the anticyclone flow of the Asian summer monsoon [29].

During winter, and especially in the month of February, dust emissions have been linked to Saharan cyclones and may contribute to the total dust load over West and North Africa $[53,54]$. It was also found that February is one of the months where dust observations are very high and oscillations in various parameters have been found [20]. Meteorological data were used in the HYSPLIT model to identify the sources of the peak of these different parameters by performing back trajectories. Forward trajectories assessed the fate of this pollution for specific dates of interest.

The climatic origins of different black cloud episodes over Cairo are identified. Peaks of carbon monoxide occur during the March and April dust events from the western desert. However, AOD in the northern hemisphere is at a maximum from April to August and diminishes in December [55]. Perturbations such as these are usually the result of either wildfires or biomass burning confirming that biomass burning is a serious cause of these perturbations [55].

During summer, especially June, ozone concentrations are high where Europe's pollution contributes to Cairo's 


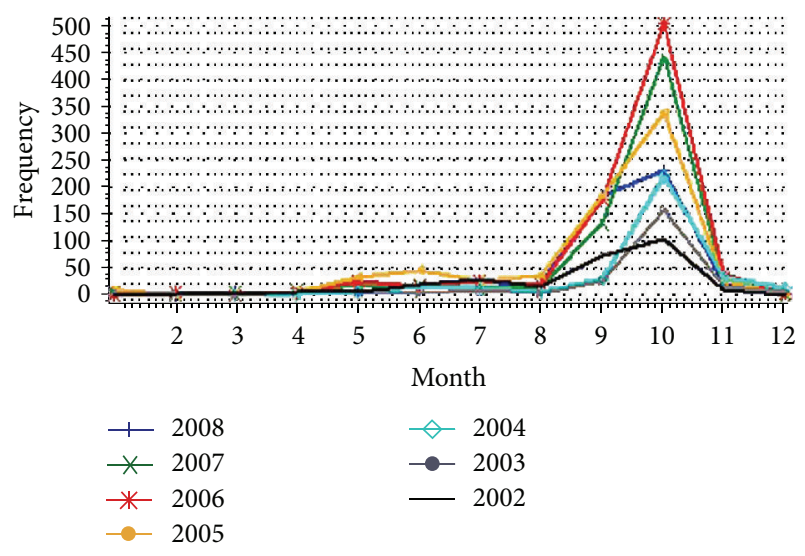

FIGURE 9: Monthly average fire counts over the Nile Delta during 2002-2009 courtesy of Marey et al., 2010 [26].

air pollution through global transport processes, most of which is transported south at low altitudes in the summer to the Mediterranean Sea, North Africa, and the Near East [44]. It was found that in 1994, the long-range or transboundary transport of ozone originating in Europe caused the ozone concentrations over the countries bordering the Mediterranean Sea to exceed the European standard and contributed to a monthly mean of 5-20 ppbv ozone [44]. The long range transported pollutants contributed to the pollution violations occurring from March to October in the Mediterranean region and at least 10 violations over Egypt, including the heavily populated Nile River Valley [42]. Additional pollution violations for health occur almost every day during the months of June, July, and August over heavily populated regions in North Africa and the near east.

Finally, during September and October, Cairo experiences black cloud peaks of ozone. Many local factors contribute to the deterioration of Cairo's air quality, including natural sources from inland deserts and anthropogenic sources such as vehicles, power plants, open air waste burning, and the cement industry [16]. It was argued that the main contributing factor to the black cloud pollution is the burning of agricultural waste during the fall season [16].

\section{Conclusions}

The following conclusions are made

(1) Data on air pollution levels of various atmospheric pollutants, greenhouse gases and parameters are available at no cost through various atmospheric and air pollution satellites. Analysis and interpretation of these data can provide very useful information and conclusions regarding atmospheric dynamics and aerosols in the atmosphere.

(2) Performing autocorrelations, cross correlations, and backward and forward trajectories helps clarify the weather pattern of a specific location.

(3) Cairo's topography of the Delta region contributes to the stagnant air that enhances air pollution episodes.
(4) Dust levels are high during the month of February, forced by Saharan cyclones.

(5) Dust storms emerging from the western desert result in peaks of carbon monoxide concentrations during March and April.

(6) During summer, especially June, high concentrations of ozone are a result of trans-boundary transportation of ozone from Europe.

(7) September and October are well known for the appearance of the "black cloud" episode. Most researchers argue that the primary source of these episodes is biomass burning caused specifically from the burning of rice straw after the rice harvesting season.

\section{References}

[1] P. Ginoux, D. Garbuzov, and N. C. Hsu, "Identification of anthropogenic and natural dust sources using moderate resolution imaging spectroradiometer (MODIS) deep blue level 2 data," Journal of Geophysical Research D, vol. 115, no. 5, Article ID D05204, 2010.

[2] Y. J. Kaufman, D. Tanrè, and O. Boucher, "A satellite view of aerosols in the climate system," Nature, vol. 419, pp. 215-223, 2002.

[3] M. D. King, Y. J. Kaufman, D. Tanrè, and T. Nakajima, "Remote sensing of tropospheric aerosols from space: past, present, and future," Bulletin of American Meteorological Society, vol. 80, no. 11, pp. 2229-2260, 1999.

[4] M. Astitha, G. Kallos, and P. Katsafados, "Air pollution modeling in the Mediterranean region: analysis and forecasting of episodes," Atmospheric Research, vol. 89, no. 4, pp. 358-364, 2008.

[5] G. Kallos, V. Kotroni, K. Lagouvardos, and A. Papadopoulos, "On the long-range transport of air pollutants from Europe to Africa," Geophysical Research Letters, vol. 25, no. 5, pp. 619-622, 1998.

[6] G. Kallos, M. Astitha, P. Katsafados, and C. Spyrou, "Longrange transport of anthropogenically and naturally produced particulate matter in the Mediterranean and North Atlantic: current state of knowledge," Journal of Applied Meteorology and Climatology, vol. 46, no. 8, pp. 1230-1251, 2007.

[7] J. Lelieveld, H. Berresheim, S. Borrmann et al., "Global air pollution crossroads over the Mediterranean," Science, vol. 298, no. 5594, pp. 794-799, 2002.

[8] E. Gerasopoulos, P. Kokkalis, V. Amiridis et al., "Dust specific extinction cross-sections over the Eastern Mediterranean using the BSC-DREAM model and sun photometer data: the case of urban environments," Annales Geophysicae, vol. 27, no. 7, pp. 2903-2912, 2009.

[9] E. Gerasopoulos, V. Amiridis, S. Kazadzis et al., "Three-year ground based measurements of aerosol optical depth over the Eastern Mediterranean: the urban environment of Athens," Atmospheric Chemistry and Physics, vol. 11, no. 5, pp. 2145-2159, 2011.

[10] M. J. Molina and L. T. Molina, "Megacities and atmospheric pollution," Journal of the Air and Waste Management Association, vol. 54, no. 6, pp. 644-680, 2004.

[11] Egypt State of the Environment Report 2005, Ministry of State of Environmental Affairs, Cairo, Egypt, 2006. 
[12] H. El-Askary and M. Kafatos, "Dust storm and black cloud influence on aerosol optical properties over Cairo and the Greater Delta region, Egypt," International Journal of Remote Sensing, vol. 29, no. 24, pp. 7199-7211, 2008.

[13] O. Favez, H. Cachier, J. Sciare et al., "Seasonality of major aerosol species and their transformations in Cairo megacity," Atmospheric Environment, vol. 42, no. 7, pp. 1503-1516, 2008.

[14] H. El-Askary, A. K. Prasad, G. Kallos, M. El-Raey, and M. Kafatos, "Analyzing black cloud dynamics over Cairo, Nile Delta region and Alexandria using aerosols and water vapor data," in Air Quality-Models and Applications, chapter 12, pp. 211-232, InTECH, 2011.

[15] H. El-Askary, "Air pollution impact on aerosol variability over mega cities using remote sensing technology: case study, Cairo, Egypt," Egyptian Journal of Remote Sensing \& Space Science, vol. 9, pp. 31-40, 2006.

[16] A. S. Zakey, M. M. Abdelwahab, and P. A. Makar, "Atmospheric turbidity over Egypt," Atmospheric Environment, vol. 38, no. 11, pp. 1579-1591, 2004.

[17] M. Abu-Allaban, A. W. Gertler, and D. H. Lowenthal, "A preliminary apportionment of the sources of ambient PM10, PM2.5, and VOCs in Cairo," Atmospheric Environment, vol. 36, no. 35, pp. 5549-5557, 2002.

[18] M. Abu-Allaban, D. H. Lowenthal, A. W. Gertler, and M. Labib, "Sources of PM10 and PM2.5 in Cairo's ambient air," Environmental Monitoring and Assessment, vol. 133, no. 1-3, pp. 417-425, 2007.

[19] M. El-Metwally, S. C. Alfaro, M. Abdel Wahab, and B. Chatenet, "Aerosol characteristics over urban Cairo: seasonal variations as retrieved from Sun photometer measurements," Journal of Geophysical Research D, vol. 113, no. 14, Article ID D14219, 2008.

[20] H. El-Askary, R. Farouk, C. Ichoku, and M. Kafatos, "Transport of dust and anthropogenic aerosols across Alexandria, Egypt," Annales Geophysicae, vol. 27, no. 7, pp. 2869-2879, 2009.

[21] E. Hossny, G. Mokhtar, M. El-Awady, I. Ali, M. Morsy, and A. Dawood, "Environmental exposure of the pediatric age groups in Cairo City and its suburbs to cadmium pollution," Science of the Total Environment, vol. 273, no. 1-3, pp. 135-146, 2001.

[22] M. Abu-Allaban, D. H. Lowenthal, A. W. Gertler, and M. Labib, "Sources of volatile organic compounds in Cairo's ambient air," Environmental Monitoring and Assessment, vol. 157, no. 1-4, pp. 179-189, 2009.

[23] S. C. Alfaro and M. Abdel Wahab, "Extreme variability of aerosol optical properties: the cairo aerosol characterization experiment case study," in Remote Sensing of the Atmosphere for Environmental Security, NATO Security through Science Series, pp. 285-299, 2006.

[24] M. Kanakidou, N. Mihalopoulos, T. Kindap et al., "Megacities as hot spots of air pollution in the East Mediterranean," Atmospheric Environment, vol. 45, no. 6, pp. 1223-1235, 2011.

[25] K. F. Mahmoud, S. C. Alfaro, O. Favez, M. M. Abdel Wahab, and J. Sciare, "Origin of black carbon concentration peaks in Cairo (Egypt)," Atmospheric Research, vol. 89, no. 1-2, pp. 161$169,2008$.

[26] H. S. Marey, J. C. Gille, H. M. El-Askary, E. A. Shalaby, and M. E. El-Raey, "Study of the formation of the "black cloud" and its dynamics over Cairo, Egypt, using MODIS and MISR sensors," Journal of Geophysical Research D, vol. 115, no. 21, Article ID D21206, 2010.

[27] H. S. Marey, J. C. Gille, H. M. El-Askary, E. A. Shalaby, and M. E. El-Raey, "Aerosol climatology over Nile Delta based on
MODIS, MISR and OMI satellite data," Atmospheric Chemistry and Physics, vol. 11, no. 20, pp. 10637-10648, 2011.

[28] A. K. Prasad, H. El-Askary, and M. Kafatos, "Implications of high altitude desert dust transport from Western Sahara to Nile Delta during biomass burning season," Environmental Pollution, vol. 158, no. 11, pp. 3385-3391, 2010.

[29] B. Barret, P. Ricaud, C. Mari et al., "Transport pathways of CO in the African upper troposphere during the monsoon season: a study based upon the assimilation of spaceborne observations," Atmospheric Chemistry and Physics, vol. 8, no. 12, pp. 3231-3246, 2008.

[30] R. G. Barry, Mountain Weather and Climate, Routledge, 1992.

[31] D. P. Edwards, L. K. Emmons, D. A. Hauglustaine et al., "Observations of carbon monoxide and aerosols from the Terra satellite: northern hemisphere variability," Journal of Geophysical Research D, vol. 109, no. 24, pp. 1-17, 2004.

[32] S. S. Kulawik, J. Worden, A. Eldering et al., "Implementation of cloud retrievals for Tropospheric Emission Spectrometer (TES) atmospheric retrievals: part 1. Description and characterization of errors on trace gas retrievals," Journal of Geophysical Research D, vol. 111, no. 24, Article ID D24204, 2006.

[33] M. W. Shephard, H. M. Worden, K. E. Cady-Pereira et al., "Tropospheric Emission Spectrometer nadir spectral radiance comparisons.," Journal of Geophysical Research, vol. 113, no. D115, Article ID D15S05, 2008.

[34] C. P. Rinsland, M. Luo, M. W. Shephard et al., "Tropospheric emission spectrometer (TES) and atmospheric chemistry experiment (ACE) measurements of tropospheric chemistry in tropical southeast Asia during a moderate El Niño in 2006," Journal of Quantitative Spectroscopy and Radiative Transfer, vol. 109, no. 10, pp. 1931-1942, 2008.

[35] J. A. Logan, I. Megretskaia, R. Nassar et al., "Effects of the 2006 El Niño on tropospheric composition as revealed by data from the Tropospheric Emission Spectrometer (TES)," Geophysical Research Letters, vol. 35, no. 3, Article ID L03816, 2008.

[36] R. Beer, M. W. Shephard, S. S. Kulawik et al., "First satellite observations of lower tropospheric ammonia and methanol," Geophysical Research Letters, vol. 35, no. 9, Article ID L09801, 2008.

[37] Y. Choi, Y. Wang, Q. Yang et al., "Spring to summer northward migration of high $\mathrm{O} 3$ over the western North Atlantic," Geophysical Research Letters, vol. 35, no. 4, Article ID L04818, 2008.

[38] R. Beer, "TES on the aura mission: scientific objectives, measurements, and analysis overview," IEEE Transactions on Geoscience and Remote Sensing, vol. 44, no. 5, pp. 1102-1105, 2006.

[39] M. R. Schoeberl, A. R. Douglass, and E. Hilsenrath, "Foreword to the special issue on the EOS aura mission," IEEE Transactions on Geoscience and Remote Sensing, vol. 44, no. 5, p. 1063, 2006.

[40] H. M. Worden, J. A. Logan, J. R. Worden et al., "Comparisons of Tropospheric Emission Spectrometer (TES) ozone profiles to ozonesondes: methods and initial results," Journal of Geophysical Research D, vol. 112, no. 3, Article ID D03309, 2007.

[41] K. W. Bowman, D. Jones, J. Logan et al., "Impact of surface emissions to the zonal variability of tropical tropospheric ozone and carbon monoxide for november 2004," Atmospheric Chemistry and Physics Discussions, vol. 8, no. 1, pp. 1505-1548, 2008.

[42] D. Fu, J. R. Worden, X. Liu, S. S. Kulawik, K. W. Bowman, and V. Natraj, "Characterization of ozone profiles derived from Aura TES and OMI radiances," Atmospheric Chemistry and Physics, vol. 13, no. 6, pp. 3445-3462, 2013. 
[43] H. M. Worden, M. N. Deeter, C. Frankenberg et al., "Decadal record of satellite carbon monoxide observations," Atmospheric Chemistry and Physics, vol. 13, pp. 837-850, 2013.

[44] B. N. Duncan, J. J. West, Y. Yoshida, A. M. Fiore, and J. R. Ziemke, "The influence of European pollution on ozone in the Near East and northern Africa," Atmospheric Chemistry and Physics, vol. 8, no. 8, pp. 2267-2283, 2008.

[45] S. Chandra, J. R. Ziemke, P. K. Bhartia, and R. V. Martin, "Tropical tropospheric ozone: implications for dynamics and biomass burning," Journal of Geophysical Research D, vol. 107, no. 14, pp. 1-17, 2002.

[46] A. M. Thompson, J. C. Witte, R. D. Hudson, H. Guo, J. R. Herman, and M. Fujiwara, "Tropical tropospheric ozone and biomass burning," Science, vol. 291, no. 5511, pp. 2128-2132, 2001.

[47] M. I. Khoder, "Ambient levels of volatile organic compounds in the atmosphere of Greater Cairo," Atmospheric Environment, vol. 41, no. 3, pp. 554-566, 2007.

[48] S. D. Choi and Y. S. Chang, "Carbon monoxide monitoring in Northeast Asia using MOPITT: effects of biomass burning and regional pollution in April 2000," Atmospheric Environment, vol. 40, no. 4, pp. 686-697, 2006.

[49] J. R. Ziemke, S. Chandra, M. R. Schoeberl et al., "Intra-seasonal variability in tropospheric ozone and water vapor in the tropics," Geophysical Research Letters, vol. 34, no. 17, Article ID L17804, 2007.

[50] H. Bremer, J. Kar, J. R. Drummond et al., "Spatial and temporal variation of MOPITT CO in Africa and South America: a comparison with SHADOZ ozone and MODIS aerosol," Journal of Geophysical Research D, vol. 109, no. 12, pp. D12304-10, 2004.

[51] K. Mohanakumar, Stratosphere Troposphere Interactions: An Introduction, Springer, 2008.

[52] H. El-Askary, A. K. Prasad, G. Kallos, M. El-Raey, and M. Kafatos, "Analyzing black cloud dynamics over Cairo,Nile Delta region and Alexandria using aerosols and water vapor data," in Air Quality-Models and Applications, chapter 12, pp. 211-232, InTECH, 2011.

[53] A. S. Goudie and N. J. Middleton, "Saharan dust storms: nature and consequences," Earth-Science Reviews, vol. 56, no. 1-4, pp. 179-204, 2001.

[54] D. B. Karam, C. Flamant, J. Cuesta, J. Pelon, and E. Williams, "Dust emission and transport associated with a Saharan depression: February 2007 case," Journal of Geophysical Research D, vol. 115, no. 13, Article ID D00H27, 2010.

[55] V. Naik, D. L. Mauzerall, L. W. Horowitz, M. D. Schwarzkopf, V. Ramaswamy, and M. Oppenheimer, "On the sensitivity of radiative forcing from biomass burning aerosols and ozone to emission location," Geophysical Research Letters, vol. 34, no. 3, Article ID L03818, 2007. 

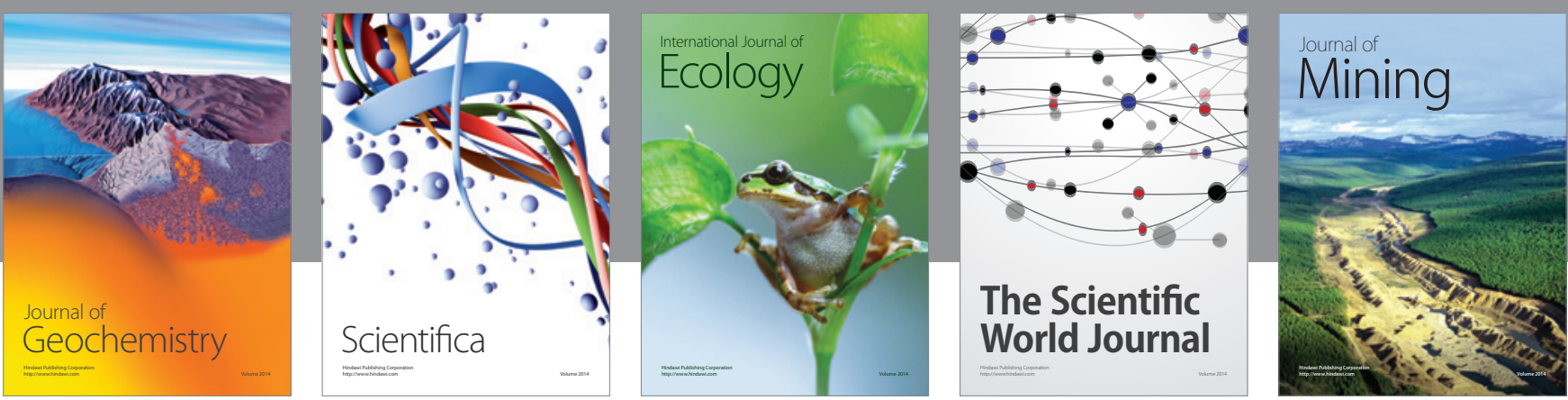

The Scientific World Journal
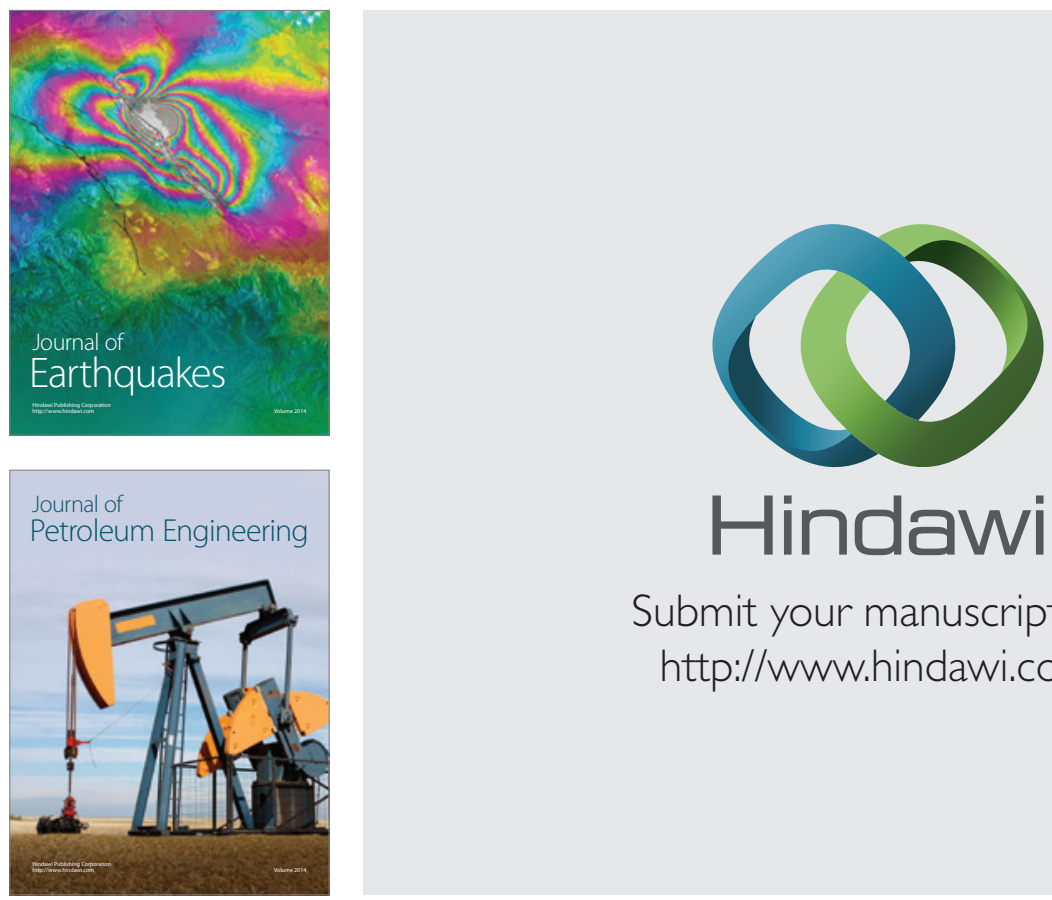

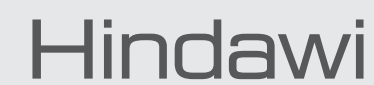

Submit your manuscripts at

http://www.hindawi.com
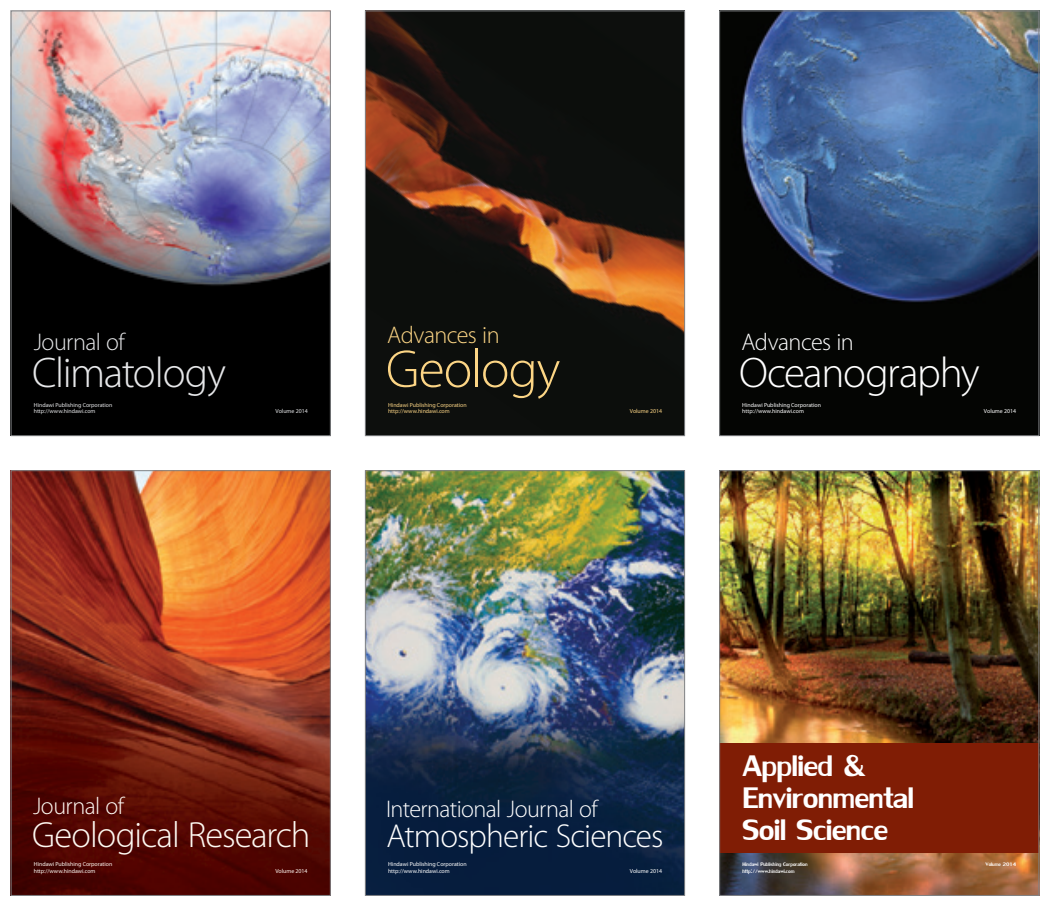
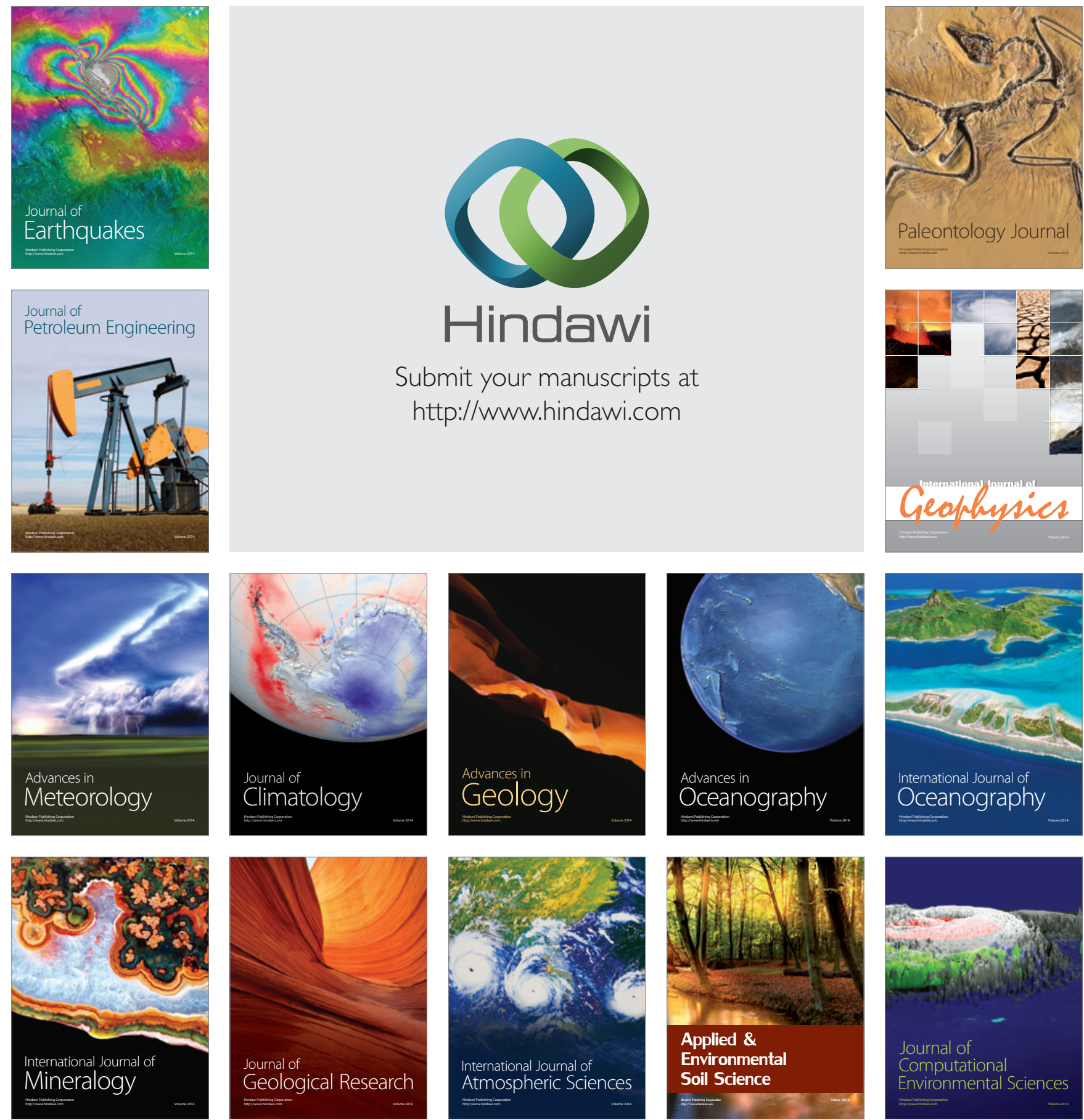